\title{
Growth response following green crown pruning in plantation-grown Eucalyptus pilularis and Eucalyptus cloeziana
}

\author{
Philip J. Alcorn, Jürgen Bauhus, R. Geoff B. Smith, Dane Thomas, Ryde James, \\ and Adrienne Nicotra
}

\begin{abstract}
Pruning of live branches is performed to enhance wood quality in plantation trees. Stem, branch and wood properties may be altered following pruning from below, but the extent and duration of such effects are unknown for many plantation Eucalyptus species. The effect of $0 \%, 20 \%, 50 \%$, and $70 \%$ green crown length removal on growth and wood quality was examined in 3.5-year-old plantation-grown Eucalyptus pilularis Sm. (blackbutt) and Eucalyptus cloeziana $\mathrm{F}$. Muell. (Gympie messmate) trees on two subtropical sites in eastern Australia. Growth increment of the stem at breast height was not affected by $20 \%$ crown removal. However, stem increment at breast height was reduced for up to 8 months with $50 \%$ crown removal and up to 12 months with $70 \%$ crown removal. Pruning had no impact on height growth. However, the height of trees pruned to $70 \%$, relative to the height of the surrounding unpruned trees, was temporarily reduced 12 months after pruning in both species. Stem form, stem taper, wood density, and residual branch growth above the pruned zone were unaffected by pruning. Owing to the fast vertical crown expansion, trees were able to rapidly compensate for leaf area removal without long-term reductions in stem growth. The implications for management operations utilizing pruning as a means of enhancing timber quality are discussed.
\end{abstract}

Résumé : On procède à l'élagage des branches vivantes pour améliorer la qualité du bois des arbres en plantation. Les propriétés du tronc, des branches et du bois peuvent être modifiées à la suite de l'élagage par le bas mais l'ampleur et la durée de ces effets sont inconnues chez plusieurs espèces d'Eucalyptus utilisées en plantation. L'effet de l'enlèvement de $0 \%, 20 \%, 50 \%$ et $70 \%$ de la longueur de la cime vivante sur la croissance et la qualité du bois a été étudié chez des tiges d'Eucalyptus pilularis Sm. et d'Eucalyptus cloeziana F. Muell. âgées de 3,5 ans et cultivées en plantation dans deux stations subtropicales dans l'est de l'Australie. L'accroissement du tronc à hauteur de poitrine n'a pas été affecté par l'élagage de $20 \%$ de la cime. Cependant, l'accroissement du tronc à hauteur de poitrine a été réduit pour une durée pouvant aller jusqu'à huit mois par l'élagage de $50 \%$ de la cime et jusqu'à 12 mois par l'élagage de $70 \%$ de la cime. L'élagage n'a pas affecté la croissance en hauteur. Cependant, la hauteur des arbres élagués à $70 \%$, relativement à la hauteur des arbres voisins non élagués, a été temporairement réduite 12 mois après l'élagage chez les deux espèces. La forme et le défilement du tronc, la densité du bois et la croissance des branches résiduelles au-dessus de la zone élaguée n'ont pas été affectés par l'élagage. À cause de l'expansion verticale rapide du tronc, les arbres ont été capables de compenser rapidement la réduction de la surface foliaire sans subir de réduction à long terme de la croissance du tronc. Les implications sur les opérations d'aménagement qui ont recours à l'élagage pour améliorer la qualité du bois sont discutées.

[Traduit par la Rédaction]

\section{Introduction}

Green crown pruning is employed to enhance timber quality in tree plantations. By removing the lower branches from the stem, knots and branch-related defects can be restricted to a central knotty core (Montagu et al. 2003). Following the healing of branch wounds on the stem, high-value knot- free timber may be produced. The rapid removal of photosynthetically active leaf area from the crown, however, has the potential to reduce tree productivity. Decreasing diameter growth with increasing pruning intensity has been reported for a wide range of commercial conifer (e.g., Cown 1973; Karani 1978), eucalypt (e.g., Lückhoff 1967; Pinkard and Beadle 1998), and acacia (e.g., Majid and Paudyal

Received 16 February 2007. Accepted 21 September 2007. Published on the NRC Research Press Web site at cjfr.nrc.ca on 18 March 2008.

P.J. Alcorn ${ }^{1,2}$ and R. James. School of Resources, Environment and Society, The Australian National University, Canberra, ACT 0200, Australia.

J. Bauhus. School of Resources, Environment and Society, The Australian National University, Canberra, ACT 0200, Australia; Institute of Silviculture, Freiburg University, D-79085 Freiburg, Germany.

R.G.B. Smith and D. Thomas. Forests NSW, P.O. Box J19, Coffs Harbour NSW 2450, Australia.

A. Nicotra. School of Botany and Zoology, The Australian National University, Canberra, ACT 0200, Australia.

${ }^{1}$ Corresponding author (e-mail: philip.alcorn@anu.edu.au).

${ }^{2}$ Present address: School of Botany and Zoology, The Australian National University, Canberra, ACT 0200, Australia. 
1992) tree species. However, some species can tolerate removal of part of the live crown without suffering long-term depressions in tree growth or size (Pinkard and Beadle 1998; Zeng 2003). Understanding the intensity of live crown removal that reduces growth is critical to the development of appropriate pruning regimes that minimize long-term growth reductions.

Pruning also has the potential to alter growth along the stem axis and hence taper. Following the removal of branches from the lower stem, growth of the upper part of the pruned region, closer to the green crown, can be favoured leading to more cylindrical stem forms (Larson 1965). Short-term pruning studies in eucalypts (e.g., Pinkard and Beadle 1998), acacia (e.g., Majid and Paudyal 1992) and conifers (e.g., Kaumi 1980; Schmidt and Wardle 2002) have reported reduced stem taper. While this reduction is desirable in increasing the recovery of sawn wood from logs, changes may only be transitory and not maintained until final harvest (e.g., Sutton and Crowe 1975; Bredenkamp et al. 1980).

Pruning is commonly completed as a selective regime where only a proportion of the dominant and codominant stems in the stand are pruned. As a consequence, competition from surrounding unpruned stems has the potential to reduce the competitive ability of pruned stems within the stand (Smith et al. 1997), particularly under severe pruning treatments (Sutton and Crowe 1975; Dakin 1982).

Stimulation of branch growth above the immediate pruned stem section is undesirable when branches are pruned in several lifts (stem lengths) to achieve a particular pruned stem length. Larger branches may increase the cost of pruning (Gerrand et al. 1997a), the wounds may take longer to overgrow (Montagu et al. 2003), and the potential for fungal infection increases with larger branch wounds (Mohammed et al. 2000). When additional lifts are not completed, larger branch development may lead to increased branch-knot size and potentially lower final product value in the unpruned $\log$ directly above the pruned zone.

Changes in assimilate supply induced by pruning may alter the partitioning of biomass within stems and has the potential to affect wood density, an important attribute of wood quality. A number of recent pruning studies have reported decreases in wood density in eucalypts with pruning (Vale et al. 2002; Thomas et al. 2006). Thomas et al. (2006) found lower wood density in pruned eucalypt seedlings was associated with reductions in fibre cell wall thickness and an increase in the ratio of lumen to cell wall area within wood. Large reductions in wood density are undesirable, in particular if this results in lower timber density at final harvest.

The broad objective of this study was to assess the effect of pruning intensity on height and diameter growth, stem size, taper and form, canopy dominance, branch size development and wood density in Eucalyptus pilularis Sm. (blackbutt) and Eucalyptus cloeziana F. Muell (Gympie messmate). These species are commercially important subtropical eucalypt plantation tree species in northern New South Wales (NSW) and southeastern Queensland (QLD), Australia. Large areas of both species have been established with the intention of producing high-value timber (Dickinson et al. 1998; Bruskin 1999), and pruning is being investigated as a means of reducing the size of the knotty core as neither species sheds branches rapidly (Smith et al. 2006). To date, pruning research in Australia has focused almost entirely on two temperate eucalypt species, Eucalyptus globulus Labill (Tasmanian blue gum) and Eucalyptus nitens (H. Deane \& Maiden) Maiden (shining gum) (e.g., Pinkard 2002, 2003). The applicability of prior research to subtropical eucalypt plantation species, which can display large differences in crown architecture (e.g., leaf area per unit ground area) (Beadle 1997), leaf physiology (Montagu et al. 2003), and branch characteristics (Smith et al. 2006) is unknown. We tested the specific hypotheses that (1) trees could compensate for moderate levels of leaf area removal without long-term $(<2$ years) reductions in stem growth or change in relative crown position; (2) increased pruning intensity results in reduced stem growth; (3) increased pruning intensity results in reduced stem taper; (4) pruning results in increased branch growth above the pruned zone; and (5) severe pruning decreases wood density.

\section{Materials and methods}

\section{Study sites and experimental design}

Pruning experiments were established on two sites on the north coast of NSW. The Woodcock site is a high-quality (E. pilularis capable of mean annual increment $>20 \mathrm{~m}^{3} \cdot \mathrm{ha}^{-1} \cdot$ year $^{-1}$ at age 5 years as indicated from adjacent inventory plots) undulating ex-pasture site located $12 \mathrm{~km}$ northwest of Beechwood in northeastern NSW. The site contains well-drained brown dermosol and brown kandosol soils and receives an annual rainfall of $1479 \mathrm{~mm}$ (average 1920-2006 mm) (Anonymous 2007). Elevation range is $90-150 \mathrm{~m}$ above sea level. The Southgate site is a high-quality ex-pasture site located nearly $2 \mathrm{~km}$ north of Nana Glen in northeastern NSW. The site is gently sloping $\left(<4^{\circ}\right)$ with deep $(1-$ $1.5 \mathrm{~m}$ ) brown and yellow earths soils (Milford 1999). Elevation is approximately $165 \mathrm{~m}$ a.s.l. with an annual rainfall of $1435 \mathrm{~mm} \cdot \mathrm{year}^{-1}$ (average 1920-2006 mm) (Anonymous 2007).

At Woodcock, 20 blocks of E. pilularis and 20 blocks of E. cloeziana trees located on moderate south- and southeastfacing slopes $\left(<10^{\circ}\right)$ were selected for the experiment. Within each block, four trees of similar diameter at breast height $(\mathrm{DBH})$ over bark were selected. All were of codominant or dominant position within the canopy, straight and single stemmed, free of visible health defects, and surrounded by four immediate neighbours in each direction. The trees had just reached canopy closure, with the crowns touching within rows and just touching between rows. The four trees selected in each block were randomly assigned to one of four pruning treatments: $0 \%, 20 \%, 50 \%$, or $70 \%$ green crown length removal. Green crown length was defined as the distance between the tree height and the stem insertion height of the lowest green branch contained within a geometrically regular crown envelope (Soares and Tomé 2001). Between 30 July and 3 August 2004, branches were pruned to a height corresponding to the assigned level of green crown removal. The resulting mean pruning heights the four pruning treatments $(0 \%, 20 \% 50 \%$, and $70 \%)$ for E. pilularis were $0,5.5,7.6$, and $9.0 \mathrm{~m}$ and $0,2.4,4.5$, and $5.7 \mathrm{~m}$ for E. cloeziana, respectively. Branches were pruned perpendicular to the branch axes as close to the stem as pos- 
Table 1. Characteristics of trees used in pruning experiments at Southgate and Woodcock sites.

\begin{tabular}{|c|c|c|c|c|}
\hline \multirow[b]{2}{*}{ Characteristic } & \multicolumn{2}{|l|}{ Southgate } & \multicolumn{2}{|l|}{ Woodcock } \\
\hline & Eucalyptus pilularis & Eucalyptus cloeziana & Eucalyptus pilularis & Eucalyptus cloeziana \\
\hline Stocking $\left(\right.$ stems $\left.\cdot h^{-1}\right)$ & 1250 & 1250 & $1136-1250$ & $1136-1250$ \\
\hline Spacing $(\mathrm{m})$ & $4 \times 2$ & $4 \times 2$ & $4 \times 2.2-2.0$ & $4 \times 2.2-2.0$ \\
\hline Mean height (m) & $10.1(0.2)$ & $11.0(0.4)$ & $11.4(0.2)$ & $7.7(0.2)$ \\
\hline Height range $(\mathrm{m})$ & $8.2-11.4$ & $9.1-12.8$ & $9.3-13.4$ & $5.8-10.0$ \\
\hline Mean $\mathrm{DBH}^{*}(\mathrm{~cm})$ & $10.9(0.2)$ & $11.5(0.3)$ & $12.0(0.3)$ & $8.6(0.2)$ \\
\hline $\mathrm{DBH}$ range $(\mathrm{cm})$ & $9.2-12.3$ & $9.5-13.5$ & $9.5-16.7$ & $6.7-10.9$ \\
\hline$H / D$ ratio $^{\dagger}(\mathrm{cm} / \mathrm{cm})$ & $93(3)$ & $96(3)$ & $97(2)$ & $90(1)$ \\
\hline Green crown height $(\mathrm{m})$ & $3.7(0.3)$ & $0.8(0.2)$ & $3.9(0.1)$ & $1.1(0.1)$ \\
\hline Live crown ratio & $0.63(0.02)$ & $0.92(0.01)$ & $0.66(0.02)$ & $0.86(0.01)$ \\
\hline Mean projected crown area $\left(\mathrm{m}^{2}\right)$ & $11.0(0.8)$ & $14.3(1.0)$ & $12.7(0.5)$ & $12.3(0.5)$ \\
\hline Crown area range $\left(\mathrm{m}^{2}\right)$ & $7.6-13.5$ & $8.5-20.8$ & $7.7-28.5$ & $7.9-21.4$ \\
\hline Number of trees & 28 & 28 & 80 & 80 \\
\hline
\end{tabular}

Note: Values in parentheses refer to standard error of mean.

* Diameter at breast height (DBH) over bark measurements at $1.3 \mathrm{~m}$.

${ }^{\dagger} \mathrm{H} / \mathrm{D}$ ratio calculated as total height $(\mathrm{cm})$ divided by DBH $(\mathrm{cm})$.

Live crown ratio calculated as green crown length (m) divided by total height (m).

sible using pruning shears on the lower stem and pole pruning saws on the upper stem.

At Southgate, a smaller growth experiment was established with the intention of completing both growth and physiology measurements on a smaller number of trees. Four blocks of E. pilularis and four blocks of E. cloeziana trees located on a gentle east-facing slope $\left(<4^{\circ}\right)$ were selected for the experiment. The trees had just reached canopy closure, with crowns touching within rows and just touching between rows. Within each block, four trees were selected using the same criteria as the Woodcock site and trees were randomly assigned to one of four pruning treatments $(0 \%$, $20 \%, 50 \%$, or $70 \%$ green crown removal). Between 6 and 7 October 2004, branches were pruned to the heights corresponding to the level of green crown removal. The resulting mean pruning heights for the four treatments $(0 \%, 20 \%$, $50 \%$, and $70 \%$ ) for E. pilularis (0, 4.6, 6.6, and $7.9 \mathrm{~m})$ were similar to those at Woodcock, whereas pruning heights $(0,2.6,6.1$, and $8.1 \mathrm{~m})$ for E. cloeziana were generally higher than Woodcock. The differences in E. cloeziana pruned heights reflect differences in initial tree height (Table 1). Furthermore, the higher mean pruning height for E. pilularis than for E. cloeziana at both sites is the result of greater green crown lift prior to pruning (Table 1). Using fixed percentages of the green crown, as opposed to pruning to fixed stem heights above the ground, removes the effects of both crown lift and difference in initial tree height.

\section{Stem and branch measurements}

To assess growth response across pruning treatments, height $(H)$, DBH over bark, and green crown length ( $H$ minus the height to the base of the green crown), were measured quarterly (July, October, and December 2004; March, July, and November 2005; and February, May, and September 2006). All height measurements were made using a height pole and DBH measurements were made at $1.3 \mathrm{~m}$ above the ground on the upslope side of the tree. Diameter at breast height was marked and utilized as a consistent marker for both height and diameter measurements. An analysis of variance of tree size prior to pruning found no significant differences in $H, \mathrm{DBH}$, height to diameter ratio $(H / D)$ measured as tree height divided by DBH, green crown height, or live crown ratio (LCR; measured as $H$ minus the green crown length divided by $H$ ) between the four pruning treatments for either species on both sites prior to pruning. To calculate LCR for the pruned treatments, green crown length was determined as $H$ minus the height of the lowest green branch on the stem.

To assess changes in the competitive position of pruned trees within the stand, the height of the trees surrounding the central plot tree were measured in July 2004, July 2005, and September 2006 on both the Woodcock and Southgate sites and assessed relative to the height of the central treatment tree. Relative height $\left(H_{\text {rel }}\right)$ of pruned trees was calculated as

$$
H_{\text {rel }}=(\mathrm{MTH} / H) 100
$$

where MTH is the mean height of the five largest trees surrounding the central measurement tree.

To examine changes in stem diameter, increment, taper, shape, and branch growth, measurements were made on all treatment trees at Southgate. Stem diameter measurements were made at positions of $0.15,2.0,4.0,6.0$ and $8.0 \mathrm{~m}$ above the ground. Stem measurements were made in July 2004, December 2004, July 2005, February 2006, and September 2006. To examine the effect of pruning on branch size throughout the crown, the green crown of each tree was divided vertically into five zones commencing at the base: zone $1(0 \%-20 \%)$, zone $2(20 \%-50 \%)$, zone $3(50 \%-$ $70 \%)$, and zone $4(70 \%-100 \%)$ of crown length at the time of pruning. A further zone $5(>100 \%)$ was added following pruning treatments to account for new growth. Branches were located in the crown using height above the ground and azimuth (eight cardinal points). Measurements of branch diameter over bark (to the nearest $0.5 \mathrm{~mm}$ ) $30 \mathrm{~mm}$ from the base were made, and each branch was classified as being live or dead. A mobile elevated working platform was used to access the crowns to measure stem and branch diameters. Prepruning branch measurements were made in July 2004 and postpruning measurements in September 2006. 
Changes in stem taper, the rate of change in stem diameter with height above the ground $\left(\mathrm{cm} \cdot \mathrm{m}^{-1}\right)$, were determined from diameter measurements made at the top and bottom end of the four stem sections: $0.15-2.0 \mathrm{~m}, 2.0-4.0 \mathrm{~m}, 4.0-$ $6.0 \mathrm{~m}$, and 6.0-8.0 $\mathrm{m}$ at each measurement. Changes in the shape of the stem were also calculated for the same four stem sections at each measurement. A form quotient for each stem section was calculated using the formulae reported by Newnham (1988) and applied by Pinkard and Beadle (1998) as

$$
Y^{k}=X
$$

where $Y$ is the relative diameter, $X$ is the relative height, and $k$ is the form exponent. Taking the logarithm

$$
k=\ln (X) / \ln (Y)
$$

and

$$
k=\ln [(H-h) /(H-1.3)] / \ln (d / \mathrm{DBH})
$$

where $d$ is the stem diameter at height $h$. The formula assumes constant variation in shape along the stem and allows the estimation of $k$ at points along the stem (except at breast height). The shape of the stem is assumed to change from neiloid, to conoid, to quadratic paraboloid, and to cubic paraboloid when $k$ changes from $2 / 3$ to 1 to 2 to 3 , respectively.

\section{Wood density}

Measurements of wood density were made at the completion of the experiment at the Southgate site only. Stem discs were removed from tree heights corresponding to the middle of the $0 \%-20 \%, 20 \%-50 \%, 50 \%-70 \%$, and $70 \%-100 \%$ green crown lengths, starting from the base of the green crown prior to pruning. A further disc was taken midway between the $100 \%$ green crown length at the time of pruning and the final top height. Discs were removed from the wood produced since pruning. Postpruned wood development was determined from the stem diameter measurements made at the commencement and completion of the experiment. A 15-20 $\mathrm{cm}^{3}$ sample of wood from each disc was then removed from the zone of new wood produced following pruning. Volumetric displacement was used to determine the sample volume and sample density was calculated following drying at $70{ }^{\circ} \mathrm{C}$ for 5 days.

\section{Weather}

Measurements of rainfall were made using $0.2 \mathrm{~mm}$ tipping-bucket rain gauges with a bucket located $20 \mathrm{~m}$ from the experimental site at Southgate and $600 \mathrm{~m}$ from the experimental site at Woodcock. A Starlog 6003B portable data logger (Unidata Pty Ltd, Perth, Western Australia, Australia) was attached and programmed to record total rainfall at $15 \mathrm{~min}$ intervals. Rainfall was measured from August 2004 to September 2006 at Woodcock and from October 2004 to September 2006 at Southgate. It was necessary to predict rainfall using linear regression analysis between actual rainfall (for the 6 months preceding) and predicted rainfall from interpolated climate surfaces (Anonymous 2007) for the months of October and November 2005 at Woodcock and June, July, October, and November 2005 at Southgate because of battery failures. Regression coefficients of determination between measured and predicted rainfall were 0.89 at Woodcock and 0.71 at Southgate.

\section{Analysis}

Height and diameter increment, $H / D$ ratio, LCR, and $H_{\text {rel }}$ were calculated for each measurement time. One E. pilularis block at Woodcock was excluded from the analyses owing to wind damage. Repeated measures analysis of variance was used to examine differences between treatments in each species in DBH, $H$, diameter increment, height increment, $H / D$ ratio, LCR, $H_{\text {rel }}$ and stem increment, taper and $k$ for the four stem sections over the experimental period.

To examine the effect of the length of the green crown on stem growth, data was pooled for all treatments. Regression analysis was used to examine the relationship between green crown length and cumulative DBH increments at each measurement for the two species at each site.

To examine the impact of pruning treatment on the growth trajectory over the 2 year experimental period, group linear regression analysis was used to examine differences in slope between cumulative diameter increment and time since for the four pruning treatments for each species and site.

Mean branch diameter of all live branches and the percentage count of branches in three size categories (0$9.99 \mathrm{~mm}, 10-24.99 \mathrm{~mm}$, and $>25 \mathrm{~mm}$ diameter) were used to examine the effects of pruning on branch characteristics in the five crown zones before pruning and 2 years after pruning. Owing to the unbalanced nature of the branch variates with respect to crown zone by treatment, it was necessary to use residual maximum likelihood (REML) for all data analyses. Prepruning analyses for all branch parameters included all crown zones; however, branch data below crown zone 3 collected 2 years after pruning were excluded from the analyses because of very low live branch counts in both species. Random terms in the models were block, tree within block, and crown zone within tree within block, and the fixed terms in the model were pruning treatment, crown zone, and the interaction between them.

One-way analysis of variance was used to examine differences in stem density at each height for all pruning treatments. All data analyses were performed in Genstat (VSN International 2004, Hemel Hempstead, Herts, UK). A significance level of 0.05 was used for all treatment comparisons.

\section{Results}

\section{Diameter at breast height increment}

Mean DBH increment, measured as the increase in stem diameter at breast height between consecutive measurements, was not significantly affected by removal of $20 \%$ of the green crown in either species at either site. Removal of $50 \%$ green crown temporarily reduced the $\mathrm{DBH}$ increment 3-5 months after pruning in E. pilularis and 3-8 months after pruning in E. cloeziana when compared with the controls at Woodcock (Fig. 1). Slight (but not significant) reductions were also evident 2 months after pruning at Southgate. Removal of $70 \%$ of the crown resulted in large initial reductions in the $\mathrm{DBH}$ increment for up to 12 months following pruning in both species. The $\mathrm{DBH}$ increment was significantly lower than the controls for the first 6 and 
Fig. 1. Mean diameter at breast height (DBH, $1.3 \mathrm{~m})$ increments and mean DBH between successive measurements taken over 2 years following pruning to remove $0 \%, 20 \%, 50 \%$, and $70 \%$ of green crown length in Euclayptus pilularis (a, $c, e$, and $g$ ) and Eucalyptus cloeziana $(b, d, f$, and $h)$ trees at the two sites. Error bars represent the standard error of means.

(a)

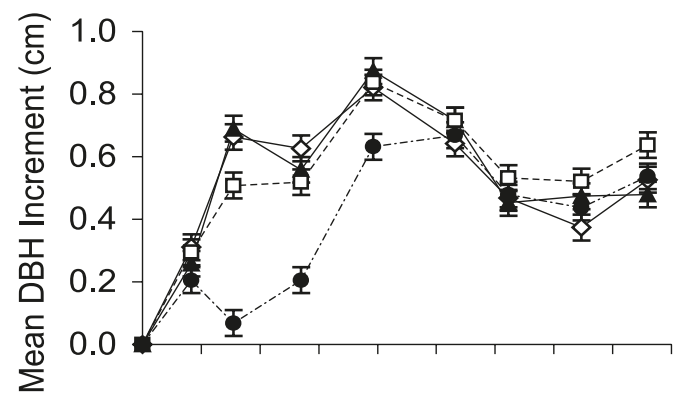

(c)

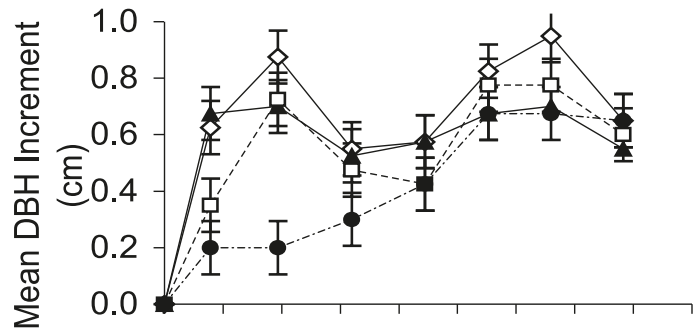

(e)

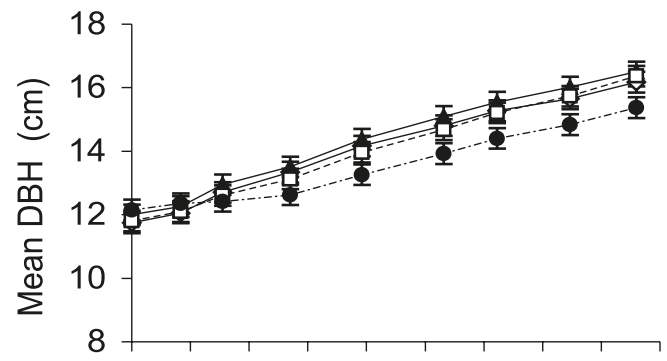

(g)

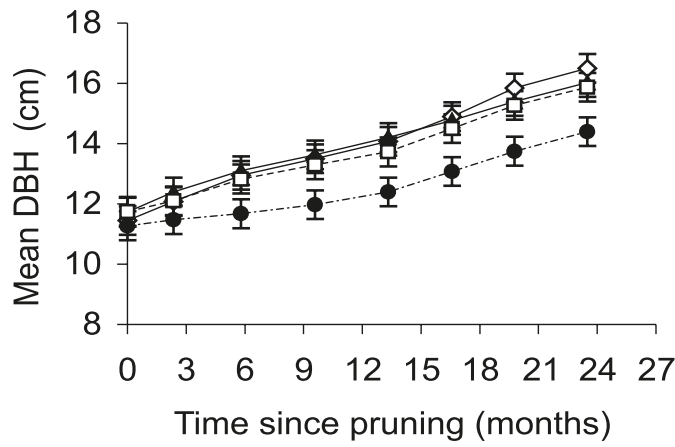

(b)

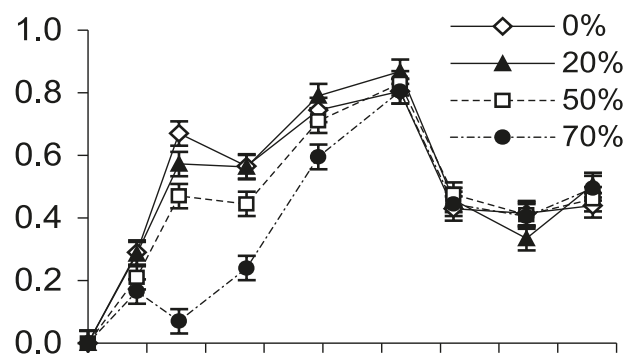

(d)

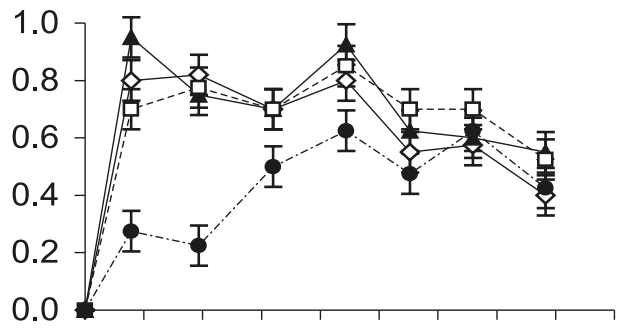

$(f)$

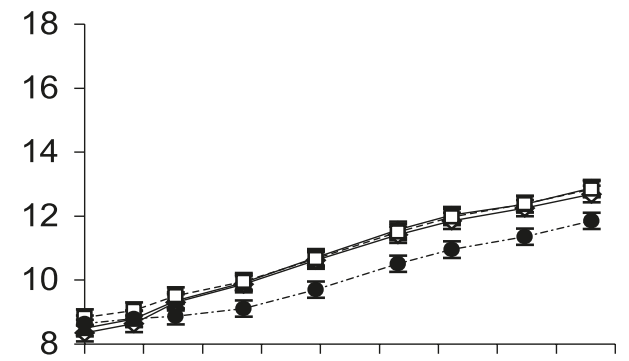

(h)

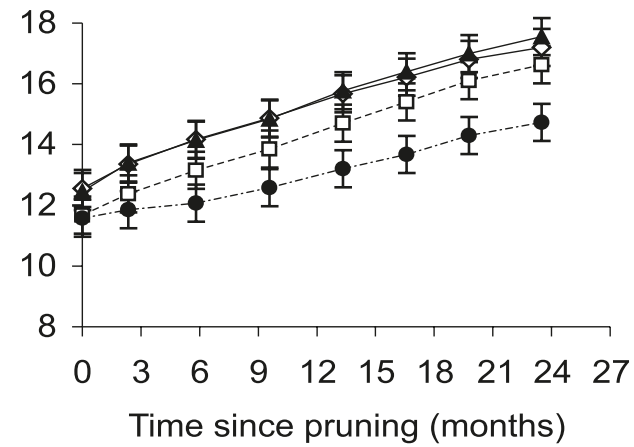

12 months following pruning at the Southgate and Woodcock sites, respectively, after which growth was not different from the controls.

Cumulative diameter increment was positively correlated with time since pruning for both species on the two sites. The slope of the relationship over the 2 year experimental period (growth trajectory), however, was significantly lower in all $70 \%$ treatments than in all other treatments, which were not significantly different.

Trends in diameter increment generally followed monthly rainfall patterns. At Woodcock, lower diameter increments for the periods $0-3$ months and 19-22 months following pruning (Figs. $1 a$ and $1 b$ ) correspond with periods of very low rainfall (105 and $114 \mathrm{~mm}$, respectively) during the same measurement periods. At Southgate, depressions in the diameter increment for the periods 6-10 months and $10-$ 13 months following pruning (Figs. $1 c$ and $1 d$ ) correspond to depressions in rainfall (228 and $114 \mathrm{~mm}$, respectively) for the same period. Total rainfall for the experimental period was 2009 and $1373 \mathrm{~mm}$ at the Woodcock and Southgate sites, respectively.

\section{Diameter at breast height}

Mean DBH for the $0 \%, 20 \%, 50 \%$, and $70 \%$ pruned treatments were $16,16,16$, and $15 \mathrm{~cm}$ for E. pilularis, respectively, and 13, 13, 13, and $12 \mathrm{~cm}$ for E. cloeziana, respectively, 2 years after pruning at Woodcock (Figs. 1e and $1 f$ ). Mean DBH for the $0 \%, 20 \%, 50 \%$, and $70 \%$ pruned treatments 2 years after pruning at Southgate were 16, 16, 16 , and $14 \mathrm{~cm}$ for E. pilularis, respectively, and 17, 18, 17, 
and $15 \mathrm{~cm}$ for E. cloeziana, respectively, (Figs. $1 g$ and $1 \mathrm{~h}$ ). Two years after pruning, the mean DBH of the $20 \%$ and $50 \%$ pruned treatments was not significantly lower than the unpruned controls in either species at the two sites, despite the small transitory reductions in the $\mathrm{DBH}$ increment in the $50 \%$ pruned treatments for up to 8 months after pruning at the Woodcock site. The removal of $70 \%$ of the crown, however, resulted in a significantly smaller $\mathrm{DBH}$ in the $70 \%$ pruned trees compared withthe unpruned controls 2 years after pruning in both species at Southgate and E. cloeziana at Woodcock. Eucalyptus pilularis trees pruned to remove $70 \%$ of the crown at Woodcock were smaller, but not significantly different from the unpruned controls 2 years after pruning.

\section{Height increment}

Height growth was between 3.3 and $2.9 \mathrm{~m} \cdot$ year $^{-1}$ for unpruned E. pilularis and between 2.1 and $3.2 \mathrm{~m} \cdot$ year $^{-1}$ for unpruned E. cloeziana at the Woodcock and Southgate sites, respectively. There were no significant differences in mean height increments between subsequent measurements in all pruning treatments in either species at the two sites.

\section{Height}

Height of E. cloeziana trees at Woodcock were significantly smaller than E. cloeziana trees at Southgate (Table 1). This difference is unlikely to have influenced the results of the experiment as the same percentages of the green crown were removed on both sites.

As for height increment, the mean tree heights of both $E$. pilularis and $E$. cloeziana were not significantly affected for the 2 years following pruning at Southgate, however, differences were evident between pruning treatments at Woodcock, with slightly but significantly higher tree height in the $50 \%$ pruned E. cloeziana treatments compared with the controls 5 and 16 months after pruning. Despite these effects, mean height was not significantly reduced with $20 \%, 50 \%$, or $70 \%$ crown removal compared with the controls in either species at the two sites 2 years after pruning.

\section{Height to diameter ratio}

The mean $H / D$ ratio of $0 \%, 20 \%, 50 \%$, and $70 \%$ pruned E. pilularis treatments were 109, 109, 108, and $113(\mathrm{~cm} /$ $\mathrm{cm}$ ), respectively, for the Woodcock site and 101, 106, 105, and $109(\mathrm{~cm} / \mathrm{cm})$, respectively, for the Southgate site. For the $0 \%, 20 \%, 50 \%$, and $70 \%$ pruned treatments of E. cloeziana, the mean $H / D$ ratio was $101,101,105$, and $119(\mathrm{~cm} /$ $\mathrm{cm}$ ), respectively, at the Woodcock site and 95, 94, 97, and $103(\mathrm{~cm} / \mathrm{cm})$, respectively, at the Southgate site. The Mean $H / D$ ratio was not significantly different between all treatments of E. pilularis at either site and for E. cloeziana at the Southgate site. In E. cloeziana at the Woodcock site, trees pruned to remove $70 \%$ of the crown exhibited a significantly higher mean $H / D$ ratio than unpruned controls from 5 months after pruning until the completion of the experiment at 2 years after pruning (Fig. 2).

\section{Competitive position}

The height of treatment trees relative to their unpruned neighbours (relative height) were not significantly affected by pruning at the Southgate site 1 and 2 years after pruning.
Fig. 2. Mean height to diameter $(H / D)$ ratio for Eucalyptus cloeziana trees measured for a period of 2 years following pruning to remove $0 \%, 20 \%, 50 \%$, and $70 \%$ green crown length at the Woodcock site in New South Wales, Australia. Error bars represent the standard error of means.

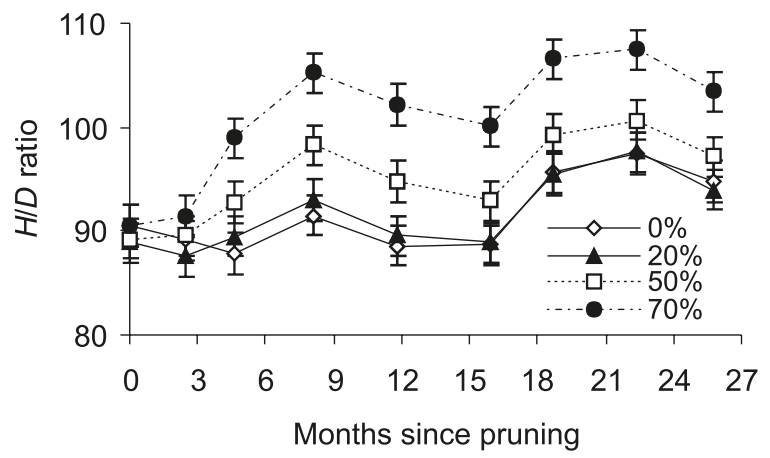

At the Woodcock site, however, trees pruned to remove $70 \%$ of the green crown were significantly shorter in relative height than trees from all other pruning treatments 1 year after pruning in both species, but recovered 2 years after pruning (Fig. 3). All other treatments were not different.

\section{Stem diameter, increment, taper, and form}

Mean stem diameter was significantly different between treatments from stump height $(0.15 \mathrm{~m})$ up to $4 \mathrm{~m}$ above the ground in both species for the 2 year experimental period. The mean stem diameter of trees pruned to remove $70 \%$ green crown length was smaller than unpruned controls in both species from 10 months after pruning until the completion of measurements at 2 years (Figs. $4 a$ and $4 b$ ). All other treatments were not significantly different from the unpruned controls up to a height of $4 \mathrm{~m}$ for the entire 2 year measurement period. Above $4 \mathrm{~m}$, treatments were not significantly different for the 2 year period following pruning.

Mean stem diameter increment, measured as the increase in stem diameter at $0.15,2,4,6$, and $8 \mathrm{~m}$ between consecutive measurements, was significantly affected by pruning up to a height of $4.0 \mathrm{~m}$ in E. cloeziana, but only at stump height $(0.15 \mathrm{~m})$ in E. pilularis. In E. cloeziana, diameter growth in the $70 \%$ pruned trees at $0.15,2.0$, and $4.0 \mathrm{~m}$ was significantly less than the unpruned controls for the first 10 months following pruning (Fig. 4d). After 10 months there were no significant differences between treatments. In E. pilularis, the stem diameter increment at $0.15 \mathrm{~m}$ in the $70 \%$ pruned trees was significantly lower than unpruned controls from 2 to 10 months after pruning (Fig. 4c). After 10 months there were no significant differences between treatments. All other treatments were not significantly different from unpruned treatments.

Prior to pruning, the mean stem taper above $0.1 \mathrm{~m}$ ranged from 1.0 to $2.1 \mathrm{~cm} \cdot \mathrm{m}^{-1}$ in both species. Pruning did not alter stem taper or $k$ over the course of the experiment.

\section{Relationship between crown size and diameter at breast height growth}

The cumulative diameter increment was positively correlated with the length of the green crown for all pruning treatments from 5 to 25 months after pruning in both species at the Woodcock site. The strength of the linear relationship 
Fig. 3. Mean heights of Eucalyptus pilularis and Eucalyptus cloeziana trees in relation to their immediate neighbours measured 1 and 2 years after pruning to remove $0 \%, 20 \%, 50 \%$, and $70 \%$ of the green crown length at the Woodcock site, New South Wales, Australia. Error bars represent the standard error of means.

(a)

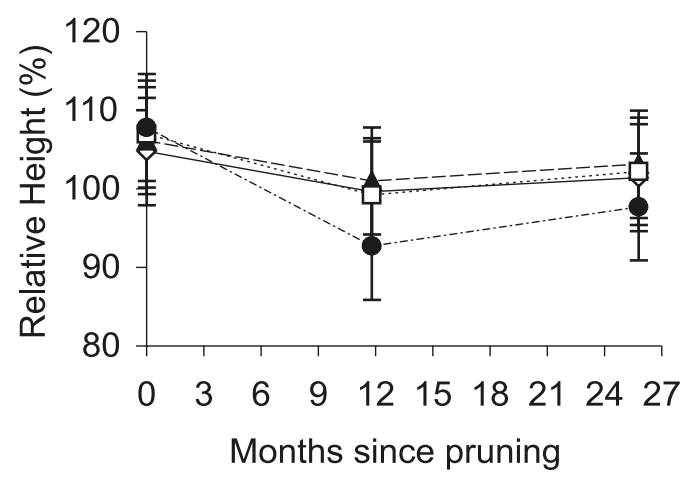

(b)

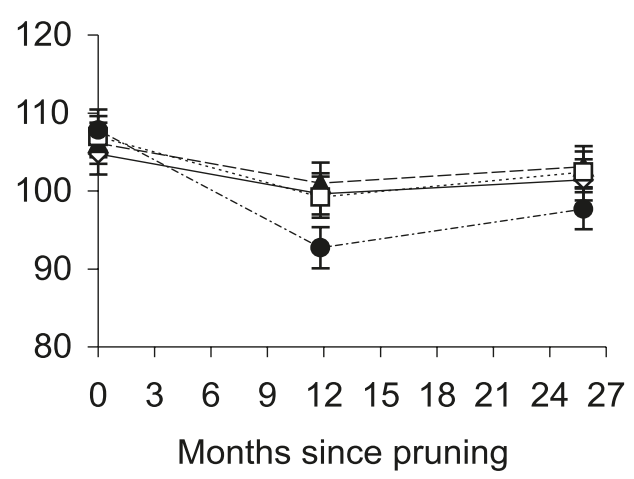

Fig. 4. Mean stem diameters 2 years following pruning and stem diameter increments between 2 and 10 months after pruning in Eucalyptus pilularis $(a$ and $c$ ) and Eucalyptus cloeziana $(b$ and $d$ ) trees at the Southgate site, New south Wales, Australia, to remove 0\%, 20\%, 50\%, and $70 \%$ of green crown length. Error bars represent the standard error of means.
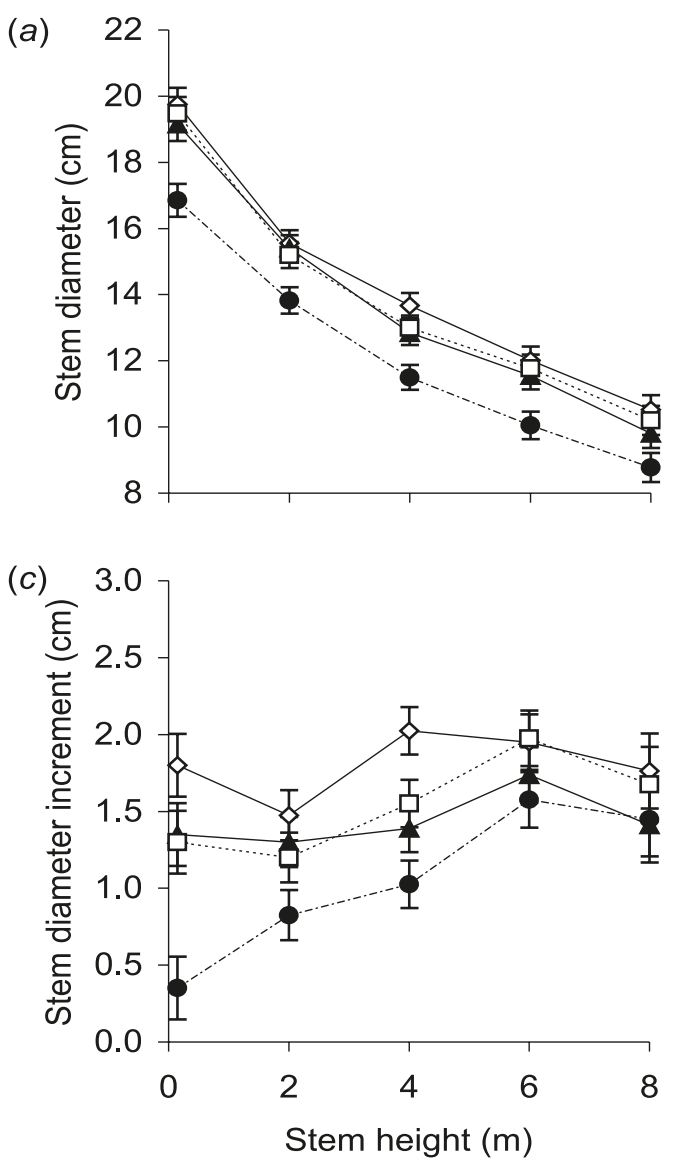

weakened from 12 months $\left(r^{2}=0.81\right.$ for E. pilularis and $r^{2}$ $=0.73$ for E. cloeziana) to 25 months $\left(r^{2}=0.64\right.$ for E. pilularis and $r^{2}=0.56$ for E. cloeziana) after pruning in both species. Similar trends existed at the Southgate site, with significant positive relationships between the cumulative diameter increment and the length of the green crown 2 to 6 months after pruning in both species $\left(r^{2}=0.55\right.$ for E. pilularis and $r^{2}=0.62$ for E. cloeziana). (b)

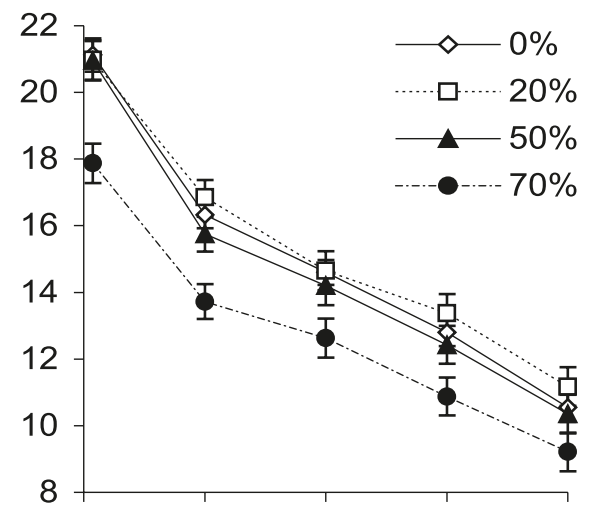

(d)

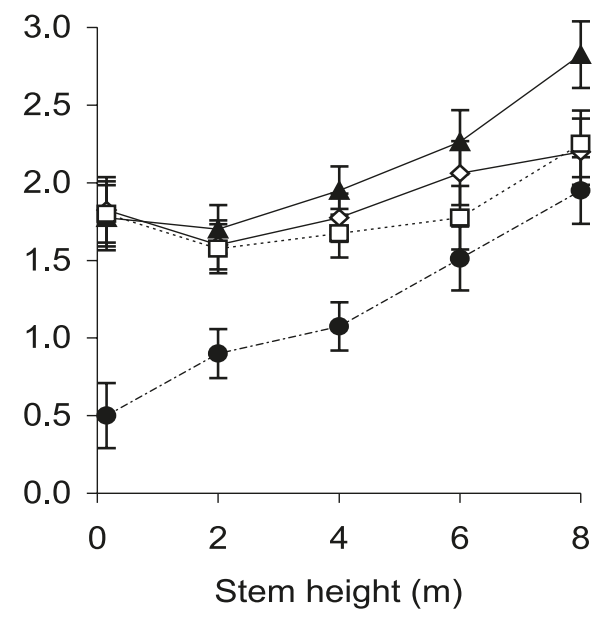

\section{Live crown ratio}

The mean LCR of unpruned E. pilularis and E. cloeziana trees decreased from 0.63 to 0.52 and 0.84 to 0.76 , respectively, at the Woodcock site and 0.67 to 0.53 and 0.93 to 0.64 , respectively, at the Southgate site over the 2 year experimental period (Fig. 5). This decrease was the result of the greater death of the lower branches compared with the increase in height growth over this period. In both species 
Fig. 5. Mean live crown ratios measured for a period of 2 years following pruning to remove 0\%, 20\%, 50\%, and 70\% of green crown length in Eucalyptus pilularis and Eucalyptus cloeziana trees at the Woodcock and Southgate sites in New South Wales, Australia. Error bars represent the standard error of means.

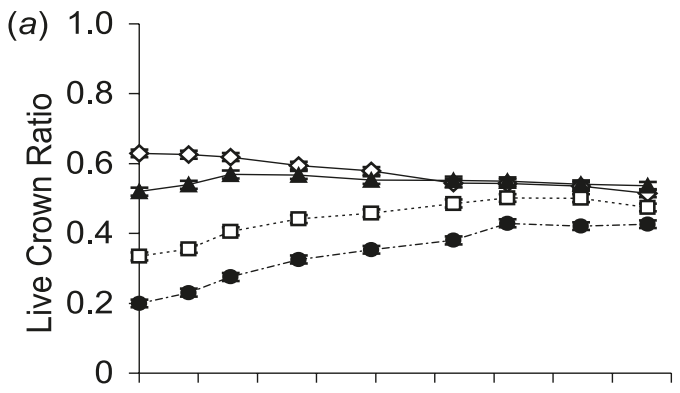

(b)
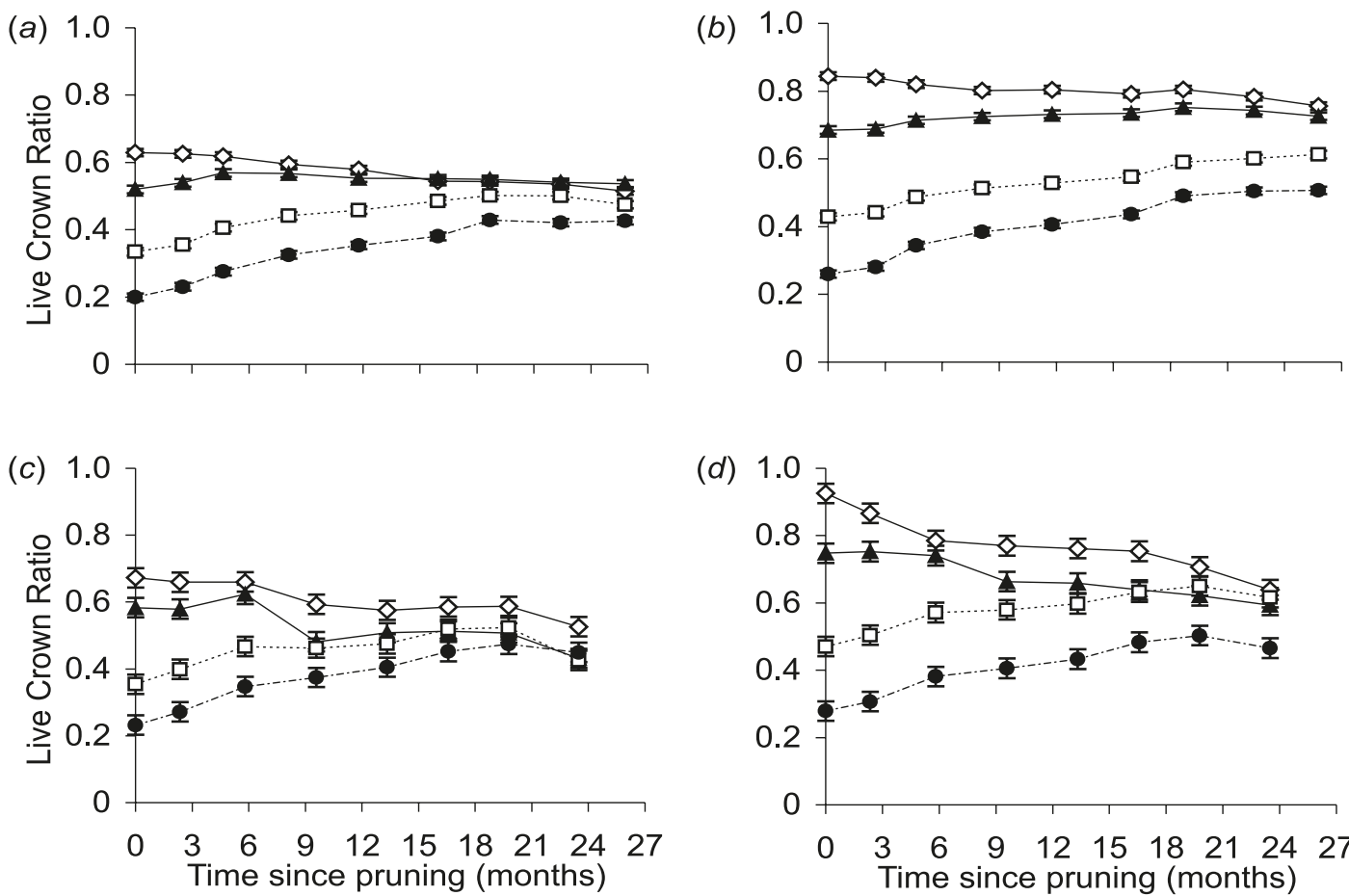

on the two sites, mean LCR was also significantly affected by pruning. Trees pruned to remove $20 \%$ of the green crown followed a similar pattern to the unpruned controls, with an initial increase and then a constant or declining LCR, resulting in a LCR not significantly different from unpruned controls 2 years after pruning in both species at either site. The LCR of trees pruned to remove $50 \%$ green crown length increased over the 2 years following pruning in both species at the two sites. Two years after pruning, the $50 \%$ pruned treatments were not significantly different from the unpruned controls at the Southgate site, whereas the LCR of both species remained significantly lower than the unpruned treatments at the Woodcock site. The LCR of the $70 \%$ pruning treatments also increased in both species on either site, but 2 years after pruning the LCR remained significantly lower than the LCR for the unpruned controls on both sites for either species.

\section{Branch size}

The mean live branch size was not significantly different between treatments in either species prior to pruning. There was a large effect of crown zone on mean live branch diameter both before and 2 years after pruning, but no effect due to pruning treatment or the interaction of pruning treatment with crown zone in either species 2 years after pruning (Table 2). There was some evidence that the data for mean branch diameter may require a logarithmic transformation to stabilize the variance for both species. However, because the results obtained for the transformed and untransformed data for this variate were essentially the same, the results are presented for the untransformed data only. Mean live branch diameter for crown zones 3-5 were 27, 21, and $11 \mathrm{~mm}$, (d)

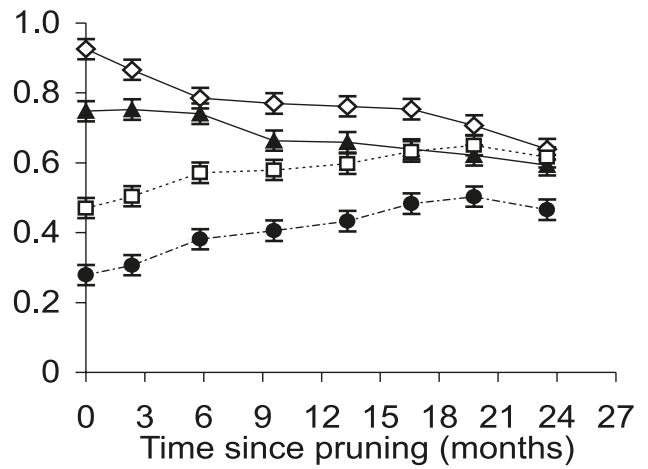

respectively, for E. pilularis and 31, 20, and $11 \mathrm{~mm}$, respectively, for E. cloeziana. The crown zones contained no live branches 2 years after pruning.

There was a large effect of crown zone on percentage live branch counts across all three size-classes (0-9.99 m, 10 $24.99 \mathrm{~m}$, and $>25 \mathrm{~mm}$ ) in both species, but no effect due to pruning treatment or the interaction of pruning treatment with crown zone in either species 2 years after pruning (Table 2), except in the 10-24.99 mm diameter branch class for E. pilularis. In this size-class, significantly higher percentages of branches were found in all pruning treatments than in the control.

\section{Density of wood}

The wood density produced following pruning was not significantly different between treatments at all stem heights in either species. The mean densities of wood produced following pruning at $10 \%, 35 \%, 60 \%, 85 \%$, and $>100 \%$ of green crown height were $497,488,478,467$, and $448 \mathrm{~kg} \cdot \mathrm{m}^{-3}$, respectively, for E. pilularis and 612, 621, 627, 623, and $599 \mathrm{~kg} \cdot \mathrm{m}^{-3}$, respectively, for E. cloeziana.

\section{Discussion}

Pruning to remove $20 \%$ or $50 \%$ of the live crown did not reduce tree size or alter dominance in $E$. pilularis and $E$. cloeziana trees, supporting our hypothesis that young eucalypts can compensate for moderate levels of leaf area removal without permanent growth reductions. We also observed greater initial diameter growth reductions at $70 \%$ rather than at $50 \%$ crown removal, which was in accordance with our second hypothesis that initial growth reductions are 
Table 2. Summary of Wald statistics to determine the effect of pruning treatment (T) and crown zone (Z) on mean branch diameter and branch counts in Eucalyptus pilularis and Eucalyptus cloeziana 2 years after pruning at the Southgate site, New South Wales, Australia.

\begin{tabular}{|c|c|c|c|c|c|c|c|c|c|}
\hline \multirow[b]{2}{*}{ Species } & \multicolumn{3}{|l|}{$\mathrm{Z}$} & \multicolumn{3}{|l|}{$\mathrm{T}$} & \multicolumn{3}{|c|}{$\mathrm{Z} \times \mathrm{T}$} \\
\hline & df & $\begin{array}{l}\text { Wald } \\
\text { statistic }\end{array}$ & $\chi$ prob. & df & $\begin{array}{l}\text { Wald } \\
\text { statistic }\end{array}$ & $\chi$ prob. & df & $\begin{array}{l}\text { Wald } \\
\text { statistic }\end{array}$ & $\chi$ prob. \\
\hline \multicolumn{10}{|l|}{ Eucalyptus pilularis } \\
\hline Branch diameter (mm) & 1 & 50.05 & $<0.001$ & 3 & 5.42 & 0.144 & 3 & 4.57 & 0.206 \\
\hline Percent branch count $(<9.99 \mathrm{~mm})$ & 1 & 391.76 & $<0.001$ & 3 & 5.27 & 0.153 & 3 & 4.29 & 0.232 \\
\hline Percent branch count $(<10-24.99 \mathrm{~mm})$ & 1 & 12.78 & $<0.001$ & 3 & 6.36 & 0.095 & 3 & 8.30 & $0.040 *$ \\
\hline Percent branch count $(>25 \mathrm{~mm})$ & 1 & 5.80 & 0.016 & 3 & 6.51 & 0.089 & 3 & 5.95 & 0.114 \\
\hline \multicolumn{10}{|l|}{ Eucalyptus cloeziana } \\
\hline Branch diameter $(\mathrm{mm})$ & 1 & 160.99 & $<0.001$ & 3 & 7.40 & 0.060 & 3 & 6.39 & 0.094 \\
\hline Percent branch count $(<9.99 \mathrm{~mm})$ & 1 & 531.55 & $<0.001$ & 3 & 8.41 & 0.038 & 3 & 3.23 & 0.358 \\
\hline Percent branch count $(<10-24.99 \mathrm{~mm})$ & 1 & 59.52 & $<0.001$ & 3 & 7.00 & 0.072 & 3 & 3.59 & 0.310 \\
\hline Percent branch count $(>25 \mathrm{~mm})$ & 1 & 8.41 & 0.004 & 3 & 4.94 & 0.176 & 3 & 4.41 & 0.221 \\
\hline
\end{tabular}

Note: $\times$ represents the interaction of pruning treatment $(\mathrm{T})$ and crown zone $(\mathrm{Z})$.

*Denotes a significant $\mathrm{P} \times \mathrm{T}$ interaction.

greater at higher pruning intensity. Our third, forth, and fifth hypotheses that increased pruning severity would decrease stem taper, increase residual branch growth, and decrease wood density were all rejected as stem taper, branch size, and wood density were not affected by pruning treatments.

Diameter increment at breast height was more sensitive to pruning effects than height increment in both species. This finding is consistent with other studies in Eucalyptus grandis W. Hill ex Maid. (Lückhoff 1967; Schönau 1974), E. nitens (Pinkard and Beadle 1998; Pinkard 2002), E. pilularis, E. cloeziana, Eucalyptus dunnii Maiden, E. grandis (Smith et al. 2006), Pinus sylvestris L. (Uotila and Mustonen 1994), and Pinus radiata D. Don. (Sutton and Crowe 1975), which have also shown diameter increment to be more sensitive to pruning than height increment. These results can be explained using the hierarchy of carbon allocation in trees, where carbon invested in height growth through production of new shoots and foliage has priority over carbon invested in diameter growth (Waring and Schlesinger 1985). Our results showed that the $\mathrm{DBH}$ increment was closely related to the size of the green crown soon after pruning for both species at the two sites. This suggests that the recovery in stem growth rates was closely related to the green crowns' capacity to supply assimilates.

Our findings demonstrated that the severity of pruning influences the growth response. The recovery of diameter increment following removal of up to $50 \%$ of the green crown was rapid for both species with no adverse long-term (>2 years) impacts on tree size. This was not the case with the removal of $70 \%$ of the green crown, with severe initial reductions in stem size and changed growth trajectory 2 years after pruning, despite a full growth recovery on both sites. These findings are consistent with pruning studies on E. grandis, a subtropical eucalypt, conducted on a highquality ( $>4 \mathrm{~m}$ in height per year) site that reported negligible effects on DBH and height growth with $<50 \%$ crown removal (Bredenkamp et al. 1980). Trees of E. pilularis and E. cloeziana, however, may be slightly more sensitive to moderate pruning ( $50 \%$ crown removal) than temperate $E$. nitens, which displayed no reductions in $\mathrm{DBH}$ or height growth following moderate pruning on a high quality
(3.8 $\mathrm{m}$ in height per year) site and moderately high-quality (2.5 $\mathrm{m}$ in height per year) site (Pinkard and Beadle 1998). Differences in crown architecture (e.g., leaf area index and vertical leaf distribution), leaf physiology (e.g., photosynthetic capacity), pruning severity (e.g., pruning removing different proportions of whole tree leaf area), or resources (e.g., nutrients and water availability) may be responsible for the differences in growth response between these eucalypt species subject to the same level of crown removal. Despite these small differences, our results support Pinkard and Beadle's (2000) general conclusion that eucalypts can tolerate between $40 \%$ and $50 \%$ crown removal without long-term growth reductions.

Severe pruning often has a greater impact on diameter growth in the lower stem than on the upper stem (Larson 1965). Some studies have shown that after severe pruning, growth is concentrated on the stem section above the pruned stem section at the expense of the stem below (Møller 1960; Långström and Hellqvist 1991). We found that the size and diameter increment of the lower stem (below $4 \mathrm{~m}$ ) was only reduced in the most severe pruning treatment $(70 \%$ crown removal). These changes, however, were not large enough to produce changes in stem taper or stem form. These findings are also consistent with the findings from multiple severe pruning experiments in E. grandis (Bredenkamp et al. 1980) and $P$. radiata (Sutton and Crowe 1975), which reported no effect on stem taper at final harvest. Similarly, Pinkard and Beadle (1998) found no affect on stem taper with $50 \%$ crown removal in E. nitens, and the stem form changes with $70 \%$ crown removal were only transient.

Maintenance of dominant or codominant canopy positions of pruned trees within the stand is important in selective pruning regimes where a loss of leaf area on selected stems can decrease their competitive ability compared with their unpruned neighbours (Plumptre 1979; Gerrand et al. $1997 a$ ). The $H / D$ ratio can be used as a measure of a crown's ability to contribute to stem growth (Smith et al. 1997). Because diameter is more sensitive to a loss of vigour than height, the least competitive trees will have a higher ratio (diameter relative to height) (Smith et al. 1997). There is no evidence from either $H / D$ ratios or rela- 
tive height measurements in our study to suggest that selective pruning to remove up to $50 \%$ of the green crown length would significantly affect the canopy position of pruned trees within the stand. However, we did find that $H / D$ ratios were higher in $70 \%$ pruned trees than in unpruned trees of both species at the two sites, although the difference was only statistically significant for E. cloeziana at the Woodcock site. This suggests a reduction in the competitive ability of these trees and supports our findings of dominance loss relative to unpruned neighbours in the $70 \%$ treatments 12 months after pruning. These results suggest that thinning at the time of first pruning does not seem to be necessary for the prevention of the loss of dominance for at least 2 years following pruning with up to $50 \%$ crown removal.

Retaining unpruned stems in the stand at the time of first pruning may also be important in preventing excessive branch development in the crown directly above the pruned stem section when branches are pruned in several lifts (stem lengths) to achieve a particular pruned stem length. Large branches are undesirable because they are more expensive to prune and may increase the chance of fungal infection (Gerrand et al. 1997a). Studies in E. nitens have shown that the incidence and severity of decay is very high in branch stubs $>30 \mathrm{~mm}$ in diameter (Mohammed 1999). In our study we found no evidence for an increase in branch size or the percentage of large branches $(>25 \mathrm{~mm})$ as a result of pruning. These results are consistent with findings for $E$. nitens where pruning to remove $50 \%$ and $70 \%$ of the crown did not result in increased branch size or frequency of large branches (Pinkard and Beadle 1998).

Pruning did not appear to affect wood density in either $E$. pilularis or E. cloeziana trees. This contrasts with other eucalypt studies reporting reductions in wood density (Vale et al. 2002; Thomas et al. 2006). This may have been attributed to the relatively short duration of reduced diameter increment producing limited changes to the cell-wall thickness of fibres and (or) the ratio of cell-wall material to lumen voids in the sample taken over the 2 year growth period.

\section{Management implications}

Current pruning prescriptions for State Forests of NSW specify a target pruned bole height of $6.4 \mathrm{~m}$, with three pruning lifts to heights of $2.4 \mathrm{~m}$ at a minimum tree height of $5 \mathrm{~m}, 4.2 \mathrm{~m}$ at minimum tree height of $9 \mathrm{~m}$, and $6.4 \mathrm{~m}$ at a minimum tree height of $13 \mathrm{~m}$. Under these prescriptions, first lift pruning would remove $48 \%$ of the crown length if the crown had not lifted above the ground. Based on the results from our study, this regime will have no adverse impacts on tree size or growth on high-productivity sites provided pruning is timed to coincide with canopy closure. A prior pruning study in E. cloeziana plantations showed that only $30 \%$ of the crown length could be removed before diameter growth was significantly reduced when trees were pruned prior to canopy closure (1.4 years) (Dickinson et al. 1998). However, pruning trees around the stage of canopy closure (2.4 years) meant up to $50 \%$ of the crown could be removed before diameter growth was affected (Dickinson et al. 1998). Pruning prior to canopy closure removes well-illuminated and productive foliage from the lower crown, while pruning at canopy closure removes foliage in lower crown that is declining in productivity as a result of shading by neighbouring trees (Pinkard 2002, 2003). The effect of pruning on total crown productivity is therefore much lower after canopy closure (Pinkard and Beadle 2000). Since canopy closure had occurred at the time of pruning in our study, the removal of lower foliage, with little potential to contribute assimilate to the rest of the tree, may explain the relatively small impact of pruning on stem growth and lack of change in stem growth trajectory with $50 \%$ crown removal. The response to pruning may also vary on sites of lower productivity than those examined in this study where differences in crown size, vertical foliage distribution, timing of canopy closure, and growth rates may produce differences in the amount and type (high versus low productivity) of leaf area removed and mechanisms that are employed to compensate for pruning. Further work is needed to quantify pruning effects on sites of differing productivity.

Pruning of dead branches rather than green branches may lead to worse internal defects forming in the stems than when branches are left to shed naturally (Gerrand et al. 1997b). Studies in temperate eucalypt species have shown that pruning dead branches is undesirable as there is a tendency for dead branch stubs to become trapped and carried outward by the expanding tree, leaving a kino trace that may lead to a loss of appearance-grade timber (Neilsen and Pinkard 2000). Furthermore, the occlusion rates of pruned dead branches may be no faster than natural branch shedding (Smith et al. 2006), but further work is needed to quantify the effect of dead branch pruning in subtropical plantation tree species. We found E. pilularis trees exhibited branch mortality at the base of the stem at the time of pruning, as indicated by the low LCR of unpruned trees (Fig. 5), despite crowns just touching between rows at both sites. This suggests that the leaves of E. pilularis were shed before complete inter-row canopy closure occurred. Timing of pruning to coincide with the commencement of the rise of the green crown will be necessary in this species to avoid pruning dead branches. Further research is needed to understand the stage at which the rise of the green crown in E. pilularis commences on sites suitable for pruning.

\section{Conclusion}

Pruning to remove up to $50 \%$ of the green crown length is unlikely to adversely impact tree size or dominance in either E. pilularis or E. cloeziana on high-productivity sites. Our study has shown that trees were able to rapidly compensate for leaf area removal without long-term reductions in stem growth or size. Pruning to remove up to $70 \%$ of the green crown length, however, is likely to reduce stem diameter, alter the stem diameter growth trajectory, and potentially reduce dominance of E. pilularis and E. cloeziana. Pruning does not appear to adversely impact stem form, stem taper, residual branch growth, or wood density.

Our results demonstrate that temperate and tropical eucalypt species respond similarly to pruning and therefore may indicate that prior results on these temperate species can be applied to some extent to the tropical ones. However, such application must be made with care, as the mechanisms that lead to compensation for pruning in these tropical species may differ. The present study is part of a larger investigation of pruning effects in E. pilularis and E. cloeziana. 


\section{Acknowledgements}

We thank Forests NSW for the use of the experimental site and financial assistance with this research. Thanks to Piers Harper, Daryl Johnston and John Alcorn for field assistance. Philip Alcorn was supported by an Australian Postgraduate Award Industry scholarship (ARC Grant LP0348999) and CRC Forestry Scholarship. The manuscript benefited from constructive comments provided by two anonymous reviewers.

\section{References}

Anonymous. 2007. Natural Resource Management [online]. Available from http://www.nrm.qld.gov.au/silo/datadrill [accessed 7 February 2007].

Beadle, C.L. 1997. Dynamics of leaf and canopy development. In Management of soil, nutrients and water in tropical plantation forests. Edited by E.K.S. Nambiar and A.G. Brown. Australian Centre for International Agriculture Research (ACIAR), Canberra, Australia. ACIAR Monograph No. 43. pp. 169-212.

Bredenkamp, B.V., Malan, F.S., and Conradie, W.E. 1980. Some effects of pruning on growth and timber quality of Eucalyptus grandis in Zululand. S. Afr. For. J. 114: 29-34.

Bruskin, S. 1999. New South Wales eucalypt plantation expansion-A silvicultural perspective. In Practising Forestry Today - Proceedings of the 18th Biennial Conference of the Institute of Foresters of Australia, 3-8 October 1999, Hobart, Tasmania.. Edited by R.C. Ellis and P.J. Smethurst. Institute of Foresters of Australia, Yarralumla, Australia. pp. 152-156.

Cown, D.J. 1973. Effects of severe thinning and pruning treatments on the intrinsic wood properties of young radiata pine. N. Z. J. For. Sci. 3: 379-389.

Dakin, A.J. 1982. Pruning trial with Sugi (Cryptomeria japonica). N.Z. J. For. 27: 89-100.

Dickinson, G., Lewty, M., and White, P. 1998. Growing eucalypt plantations in southern Queensland: current forestry prescriptions and new directions. In Managing and Growing Trees Training Conference Proceedings, 19-21 October 1998, Kooralbyn, Queensland, Australia. Queensland Department of Natural Resources and Mines, Brisbane. pp. 381-385.

Gerrand, A.M., Neilsen, W.A., and Medhurst, J.L. 1997a. Thinning and pruning eucalypt plantations for sawlog production in Tasmania. Tasforests, 9: 15-34.

Gerrand, A.M., Medhurst, J.L., and Neilsen, W.A. 1997b. Research results for thinning and pruning eucalypt plantations for sawlog production in Tasmania. Forestry Tasmania. August 1997.

Karani, P.K. 1978. Pruning and thinning in a Pinus patula stand at Lendu Plantation, Uganda. Commonw. For. Rev. 57: 269-278.

Kaumi, S.Y.S. 1980. The effects of height of pruning on the growth of Cupressus benthamii and Pinus radiata. Kenya Agricultural Research Institute, Nairobi, Kenya. For. Tech. Note 40.

Långström, B., and Hellqvist, C. 1991. Effects of different pruning regimes on growth and sapwood area of Scots pine. For. Ecol. Manage. 44: 239-254. doi:10.1016/0378-1127(91)90011-J.

Larson, P.R. 1965. Stem form of young Larix as influenced by wind and pruning. For. Sci. 11: 412-424.

Lückhoff, H.A. 1967. Pruning of Eucalyptus grandis. For. S. Afr. 8: $75-85$.

Majid, N.M., and Paudyal, B.K. 1992. Pruning trial for Acacia mangium Willd. plantation in Peninsular Malaysia. For. Ecol. Manage. 47: 285-293. doi:10.1016/0378-1127(92)90280-M.

Milford, H.B. 1999. Soil landscapes of the Coffs Harbour $1: 100000$ sheet report. Department of Land and Water Conservation, Sydney, Australia.
Mohammed, C. 1999. Reduction of pruning associated decay infections in Eucalyptus nitens plantations grown for sawlog and veneer. CSIRO Forestry and Forest Products, Canberra. February 1999.

Mohammed, C., Barry, K., Battaglia, M., Beadle, C., Eyles, A., Mollon, A., and Pinkard, E. 2000. Pruning-associated stem defects in plantation E. nitens and E. globulus grown for sawlog and veneer in Tasmania, Australia. In The Future of Eucalypts for Wood Products, IUFRO Conference Proceedings, Launceston, Australia, 19-24 March. Forest Industries Association, Hobart. pp. 357-364.

Møller, C.M. 1960. The influence of pruning on the growth of conifers. Forestry, 33: 37-53.

Montagu, K.D., Kearney, D.E., and Smith, R.G.B. 2003. The biology and silviculture of pruning planted eucalypts for clear wood production - a review. For. Ecol. Manage. 179: 1-13. doi:10. 1016/S0378-1127(02)00579-0.

Neilsen, W.A., and Pinkard, E.A. 2000. Developing silvicultural regimes for sawlog and veneer production from temperate eucalypt plantations in Tasmania. In The Future of Eucalypts for Wood Products, IUFRO Conference Proceedings, Launceston, Australia, 19-24 March. Forest Industries Association, Hobart. pp. 335-342.

Newnham, R.M. 1988. A variable-form taper function. Petawawa National Forestry Institute, Petawawa, Ontario. For. Can. Inf. Rep. PI-X-83.

Pinkard, E.A. 2002. Effects of pattern and severity of pruning on growth and branch development of pre-canopy closure Eucalyptus nitens. For. Ecol. Manage. 157: 217-230. doi:10.1016/ S0378-1127(00)00647-2.

Pinkard, E.A. 2003. Physiological and growth responses related to pattern and severity of green pruning in young Eucalyptus globulus. For. Ecol. Manage. 182: 231-245. doi:10.1016/S03781127(03)00046-X.

Pinkard, E.A., and Beadle, C.L. 1998. Effects of green pruning on growth and stem shape of Eucalyptus nitens (Deane and Maiden) Maiden. New For. 15: 107-126.

Pinkard, E.A., and Beadle, C.L. 2000. A physiological approach to pruning. Int. For. Rev. 2: 295-305.

Plumptre, R.A. 1979. Pruning of fast growing pines for wood uniformity: Can you have your cake and eat it? Commonw. For. Rev. 58: 181-189.

Schmidt, T.L., and Wardle, T.D. 2002. Impact of pruning Eastern Redcedar (Juniperus virginiana). West. J. Appl. For. 17: 189193.

Schönau, A.P.G. 1974. The effect of planting espacement and pruning on growth, yield and timber density of Eucalyptus grandis. S. Afr. For. J. 88: 16-23.

Smith, D.M., Larson, B.C., Kelty, M.J., and Ashton, P.M.S. 1997. The practice of silviculture: applied forest ecology. 9th ed. John Wiley and Sons Inc., New York.

Smith, R.G.B., Dingle, J., Kearney, D., and Montagu, K. 2006. Branch occlusion after pruning in four contrasting sub-tropical eucalypt species. J. Trop. For. Sci. 18: 117-123.

Soares, P., and Tomé, M. 2001. A tree crown ratio prediction equation for eucalypt plantations. Ann. For. Sci. 58: 193-202. doi:10. 1051/forest:2001118.

Sutton, W.R.J., and Crowe, J.B. 1975. Selective pruning of radiata pine. N. Z. J. For. Sci. 5: 171-195.

Thomas, D.S., Montagu, K.D., and Conroy, J.P. 2006. Effects of leaf and branch removal on carbon assimilation and stem wood density of Eucalyptus grandis seedlings. Trees (Berl.), 20: 725733. doi:10.1007/s00468-006-0087-x.

Uotila, A., and Mustonen, S. 1994. The effect of different levels of 
green pruning on the diameter growth of Pinus sylvestris L. Scand. J. For. Res. 9: 226-232.

Vale, R.S.d., Macedo, R.L.G., Venturin, N., Mori, F.A., and Morais, A.R.d. 2002. Effect of artificial pruning on wood quality of eucalypt clones in an agrosylvopastoral system. Rev. Arvore, 26: 285-297.
Waring, R.H., and Schlesinger, W.H. 1985. Forest ecosystems: concepts and management. Academic Press, Orlando.

Zeng, B. 2003. Aboveground biomass partitioning and leaf development of Chinese subtropical trees following pruning. For Ecol. Manage. 173: 135-144. doi:10.1016/S0378-1127(01) 00821-0. 